School Choice to Lower Secondary Schools and Mechanisms of Segregation in Urban Finland

Kosunen, Sonja

2020-12

Kosunen, S, Bernelius , V , Seppänen , P \& Porkka, M 2020 , ' School Choice to Lower Secondary Schools and Mechanisms of Segregation in Urban Finland ', Urban Education , vol. 55 , no. 10 , pp. 1461-1488 . https://doi.org/10.1177/0042085916666933

http://hdl.handle.net/10138/319513

https://doi.org/10.1177/0042085916666933

acceptedVersion

Downloaded from Helda, University of Helsinki institutional repository.

This is an electronic reprint of the original article.

This reprint may differ from the original in pagination and typographic detail.

Please cite the original version. 
Kosunen, S., Bernelius, V., Seppänen, P. \& Porkka, M. (2016). Pupil admission to lower secondary schools and mechanisms of school segregation in urban Finland. Urban Education. Published online before print October 21, 2016, doi: $10.1177 / 0042085916666933$

\section{School choice to lower-secondary schools and mechanisms of segregation in urban Finland}

\section{Introduction}

School choice as a policy and practice has been introduced and studied in various forms across Western countries during the past three decades (see for England e.g. Ball, 2003, and Reay, 2004; for Sweden e.g. Bunar, 2010; for Finland e.g. Seppänen, 2003; for France e.g. van Zanten, 2009). The phenomenon can be approached from two perspectives: families choosing schools from their options in cities, and schools admitting pupils and selecting some (or all) of them according to different criteria (van Zanten, 2009). The academic debate around school choice has long been dominated by research on social and school segregation, costs, grades, social networks, identities and good parenthood (Bunar, 2010, 13). Quite a few studies focus on the educational practices of middle and higher social classes who use school choice and benefit from it in different local contexts (e.g. Ball, 2003; Power et al., 2003; Kosunen \& Seppänen, 2015a). Reay (2004: 537) has pointed out, how in the English context just as well as the old meritocratic system, also the marketized education system enabling school choice is failing the working-class families. She shows how in the English context "choice policies can have powerful detrimental effects closing down choice for disadvantaged families and exacerbating processes of social exclusion' in inner cities. (Reay, 2004: 538.) The process of school choice and its link to segregation in urban areas is thus an interesting phenomenon to investigate across contexts.

Different phenomena linked to school choice, such as urban and educational segregation and the diversification of schools along social-class lines, have recently been reported across Nordic cities (e.g., Andersson \& Malmberg, 2015; Bunar, 2010; Dovemark \& Holm, 2015; Malmberg, Andersson \& Bergsten, 2014), as happened earlier in the UK and France, for example (e.g., Butler \& Robson, 2003; Butler \& Hamnett, 2007; Oberti, 2007; Taylor, 2002; van Zanten, 2009). Studies spanning various countries and urban contexts show how the ones benefiting from the possibility of school choice tend to be different fractions of the higher social classes. Reay (2004: 549) points out the relational and interdependent nature of school choice saying that 'the choices of one group or groups in society need to be contextualized in relation to the practices of, and consequences for, other groups'. Some studies even in the Nordic countries point especially to the influence of the distinctive school choices made by the upper social classes (Bråmå, 2006; Kosunen \& Seppänen, 2015a), which 
seem to have a segregative influence on the functioning of the whole network of schools in cities. Recent Finnish studies concerning school diversification in learning outcomes (Berisha \& Seppänen, 2016; Bernelius, 2013; Hautamäki et al., 2013), urban segregation around schools (Bernelius, 2013; Bernelius \& Vaattovaara, 2016; Dhalmann et al., 2014) and parental school choice as a social-class practice (Kosunen \& Seppänen, 2015a; Kosunen, 2016; Seppänen et al., 2015a) report tendencies towards social segregation in basic schooling. At the same time, the reasons behind the accumulation of disadvantage in certain urban areas are strongly connected to the residential choices of more well-off families, who might choose to avoid or to move out of an area (Kortteinen \& Vaattovaara, 2015; Vilkama, 2011).

Despite the acknowledged increasing social and school segregation in cities, the mechanisms of the process across schools and neighbourhoods are still an underresearched field in the context of Finnish comprehensive schooling. The larger question we pose is this: Can we still talk of one comprehensive school for all in the Finnish context, given its egalitarian reputation? In this article we explore how urban segregation, school differentiation and parental choice are intertwined in the city of Espoo in the western metropolitan area of Helsinki. The research aim is to investigate the interconnections between pupil enrolment by neighbourhood and the social composition of schools. Our objective is to enhance understanding of the mechanisms that may lead to school differentiation and thereby to diversified learning environments among pupils from different socio-economic backgrounds within a historically and by-reputation egalitarian, public and tuition-free, comprehensive educational system.

By means of quantitative analysis we explore pupil enrolment into lower-secondary schools among the whole age-cohort of $12-13$-year-olds $(n=2,400)$ in the city of Espoo in the metropolitan area of Helsinki. The focus is on the mechanisms through which the inter- and intra-district school choices (within or across the city's seven catchment areas, each with between three and five schools) of pupils progressing from primary to lower-secondary schools veer away from certain schools (section 4.1) towards others (4.2), and how the pupil flows emerge as differences in socioeconomic composition among the schools in the city (4.3). The phenomenon does not refer merely to the situation in a single city, but rather concerns the ways in which urban educational choice and governance can lead to the establishment of distinctive educational paths, which by definition have no place in the uniform and public Nordic educational model.

\section{Schools and families in cities: parental-choice policies and segregation}

Schools in cities are more than mere sites of encounter: they are focal aspects of children's geographies and the organisation of family life, and play a central role in shaping social identities (Collins \& Coleman, 2008). The socio-spatial dimension of schooling and the question of privilege in residential and educational choice (see 
Butler \& Hamnett, 2007) should be given serious consideration given that schools play such an essential role in shaping youngsters' lives. This study is positioned on the urban dimension of studies in the sociology of education, which focuses on families' educational choices and segregation in urban areas. There are at least two interconnected ways of looking at school-choice policies in cities: in relation to the choice of school and the choice of housing. The former focuses on active choices related to different kinds of institutions (public or private; different tracks within them) facilitated by educational policies promoting school choice and conducted (or not conducted) by families (see Ball, 2003; Gewirtz et al., 1995; van Zanten, 2009). This viewing angle relates to the problematic field of tracking, streaming and banding the pupils within and across schools (see van Houtte et al., 2012). The choice of housing relates to the choice among families to reside near desirable schools (school choice by mortgage; see Holme, 2002; Thrupp, 2007) when there is a simultaneous policy of local school allocation and allocating schools based on the children's home addresses. Most systems combine these two perspectives, but for analytical clarity we separate them conceptually.

Choosing institutions and different tracks within them are often in focus, when school choices are studied. The academic debate on parental choice has long concentrated on the patterns by which different social classes exploit (e.g. Gewirtz et al., 1995; Lauder et al., 1999; van Zanten, 2009), do not intentionally exploit (Crozier et. al., 2008; Raveaud \& van Zanten, 2007) or may not be able to exploit (Ball et al., 1995; Ball \& Vincent, 1998; Reay \& Lucey, 2003) the available options in urban areas by choosing other than the local school. Thrupp (2007) claims in the context of New Zealand that the 'urban middle classes have always sought and been successful in finding ways to educate their children in socially advantaged schools, but have done this in different ways depending on the policies of the day' (Thrupp, 2007: 1394). Reay (2004: 543) writes about higher classes' self-exclusion (to a private school market or 'choice by mortgage': see also Curran Neild, 2005) and exit-practices (choosing selective schooling within the public market) nearby comprehensive schools with a 'sinking' reputation, and concludes that self-exclusion requires a lot of economic capital and exit high cultural capital. The space for parental choice is seen as socially influencing the pupil composition of schools, given that the choices made tend to diversify by social-class background (see Ball, 2003; Power et al., 2003; van Zanten, 2009).

The current debate, at least in Finland and other Northern European countries, concerns the question of who actually use and benefit from such choices, and whether choosing a school or a certain stream is a practice that everybody can and will follow regardless of their social background. This discussion relates to the interconnection of families' school choices and mechanisms of school segregation. Many of the studies on parental choice (e.g., Ball \& Vincent, 1998; Kosunen \& Seppänen, 2015a; van Zanten, 2009) lean on the Bourdieusian (Bourdieu, 1984) tradition of studying education as a forum of capital transformation and transmission, and educational choice as a socially divisive tool for families to ensure the reproduction of their 
position in the field in relation to others. This research approach explains our interest in the ways (educational strategies) used in the choosing of schools and streams in the urban space: what, if anything and in practice, facilitates distinction within the educational system?

The original ideology behind comprehensive schooling in the Nordic countries (Denmark, Finland, Iceland, Norway and Sweden) was to educate all children in the same schools regardless of their social and ethnic background and gender (Rinne, 2000). School enrolment was fully connected with place of residence, just like in many other contexts (see e.g., Mitchell et al., 2010). This worked well for a long time in socially mixed urban areas with relatively few levels of segregation. The cherished so-called Nordic model of education, namely one school for all, as part of an extensive welfare-state model has now been questioned, mainly due to emerging market-led education policies (Lundahl, 2016). In Finland the school choice as a policy was introduced in legislation in the late 1990s as a part of larger educational reforms promoting freedom, decentralisation and choice in education, and was reasoned by an individualistic discourse (Seppänen, 2006). This meant in practice that schools could start choosing some of their pupils to selective classes via aptitude-tests and families could start choosing schools depending on the school choice policy of their city.

School segregation is not an explicit goal in comprehensive schooling in the Nordic countries at least, rather the opposite, despite reported signs of such developments across Nordic contexts and levels of education (Östh et al., 2013). It is accepted in Finland, too, that parental choice of schools has become a social practice (Kosunen \& Carrasco, 2016), and a social-class issue in general (Seppänen et al., 2015b) on the level of choosing with whom to study rather than choosing the curriculum content in a certain subject area. The study paths of pupils from different social backgrounds are already becoming diversified at the comprehensive-school stage, meaning that pupils from different socio-economic backgrounds tend to make different choices and end up in different study groups in relation the selectiveness at comprehensive school (e.g., Seppänen et al., 2012a; 2012b; 2015a).

According to van Zanten (2009) in the context of educational choice, the essential question concerns how school choice as a process leads to the academic and social grouping of pupils. Social diversification in schools impinges on the discussion about school segregation, which may happen across or within schools by different means. Thrupp (2007) explains how segregation is undesirable for several reasons, which are related to general achievement, the resourcing of schools through pupil flows and the (limited) access of pupils to networks and power. Van Houtte and Stevens (2009), referring to the Belgian context, showed that when pupils are selected and grouped by ability, those in the group with the lowest achievement (and knowing it) might, as a group, develop more negative attitudes towards school. 
The second perspective on urban school choice in addition to families choosing schools concerns residential choice and the (de-)segregation of schools in relation to the diversification of education (see Thrupp, 2007). It is claimed that social differentiation in schools is strongly linked to urban segregation, often attributable to local school-allocation policies. Many school-choice policies have been introduced officially in order to desegregate urban schools and give children from poorer areas the chance of attending a good school outside their disadvantaged neighbourhood (Thrupp, 2007). However, studies also show how this kind of desegregation rarely happens in some contexts because, for example, the higher social classes might want to distance themselves from schools that become accessible to the lower social strata (see e.g., Holme, 2002). There is even evidence from Stockholm in Sweden of an unforeseen increase in across-school segregation following the introduction of free school choice, even if residential segregation remained on the same level as before the reform (Söderström \& Uusitalo, 2005: 20). On a larger scale, the consequences of the resulting de facto closures in schools (social, ethnic and gendered) based on pupilselection practices are assumed to serve as a basis for the emerging inequalities in society (Reay et al., 2011), which then turns the question back to the ways pupils are allocated to and grouped in schools.

School enrolment in Finland takes place mainly in relation to the choice of residence along with the local school-allocation policy (Bernelius, 2013; Dhalmann et al., 2014), the parental choice of certain schools (intra-district choice: Bernelius, 2013; Seppänen, 2003; 2006) and the offering of selective classes with a special emphasis (intra- and inter-district choices: Kosunen, 2016; Seppänen et al., 2012a; 2012b; 2015a). ${ }^{1}$ In addition, qualitative studies have shown how language choices, in practice, serve as a distinctive choice strategy across schools within catchment areas (intra-district choice: Kosunen, 2014; Seppänen \& Kosunen, 2015). However, thus far it is unknown into which extent do these policies and strategies together with families' involvement influence the social compositions of the schools.

\section{The context}

For the past decade or two Finland has been seen as having an ideal comprehensiveeducation model given the country's high performance in OECD-led reports comparing learning outcomes. The Finnish comprehensive school for 7-15-year-olds has long had the international reputation of being relatively equal and providing uniform teaching for all pupils regardless of background. In PISA-reports the learning

\footnotetext{
${ }^{1}$ In Finnish cities local schools are allocated by city officials to all pupils based on their home address. Pupils may enrol into selective classes by applying and later succeeding in an aptitude-based exam, in which the school in question measures their aptitudes in the emphasised subject area, e.g. music or arts. These classes, which are based on pupil selection on the part of the schools, are called selective classes in this study. The classes constructed via local school allocation are called general classes. The additional language choices discussed later on can be attached to either, general or selective classes. They track the local school allocation in each catchment area only to certain schools, in which the language is taught.
} 
outcomes in mathematics (mean score 519), reading (524) and science (545) are all above the average scores in OECD-countries (mean scores 494 in mathematics, 496 in reading, and 501 in science) (OECD 2014, 5). Decrease in the level of all Finnish results are reported when comparing with the past decade (OECD, 2014; Välijärvi, Kupari et al., 2015). The regional differences in PISA-reporting are claimed to be relatively small in Finland, yet slightly increasing across schools, and even if the results in the capital area are slightly contradictory (Välijärvi, Kupari et al., 2015: 131) they point at the increase of family-background effect (ibid., 137).

The education system from the comprehensive to the tertiary level in Finland is fully publicly funded and there are no official educational dead-ends. The municipalities have the main responsibility for organising compulsory schooling, which lasts nine years starting at the age of seven (Basic Education Act 628/1998, 4§, 25§). Almost all children in Finland attend public comprehensive schools, ${ }^{2}$ all of which follow the National Guidelines for the Core Curriculum up to the age of 15. The role of private actors in education is extremely limited in Finland compared to recent global trends in the privatisation of basic education (e.g., Hursh, 2015; Lubienski, 2009). Furthermore standardised testing, inspection, a detailed national curriculum, hard evaluation, competition or accountability have not been introduced into a great extent (see e.g. Simola, 2015).

The discussion of establishing school choice in Finland took place in the 1990s. Originally it was not about providing children from poorer areas with access to "better" schools and leading to desegregation of schools, but rather promoting individualisation in education as such. It resulted in the emergence of public school markets: choices between publicly funded schools. (Seppänen 2006.) Berends (2014) describes how the idea of choosing is deeply embedded in the discourse of education in the US, for example, even if the range of school-choice possibilities is vast, starting from private schools and voucher systems and going all the way to inter- and intradistrict public-school choice. Hence, "school choice" may mean many different things depending on the context. (Berends, 2014.) In Finland municipalities are obligated to appoint "a local school" for every child that he or she has the right to attend, and the allocation of local schools in municipalities must take into account "short and safe school journeys" (Basic Education Act 628/1998, 6§), without further specification in the law. In the Finnish context school choice means that pupils have the right to apply to a school other than the allocated one, and schools may select pupils if they have a

\footnotetext{
${ }^{2}$ Fewer than $3 \%$ are enrolled in fully state-subsidised independent schools run by non-profit foundations or non-municipal communities (Ministry of Education, 2007: 22), and there are no intentions to increase this share (Ministry of Education and Culture, 2012). Furthermore, the current law for comprehensive schooling (Basic Education Act 628/1998) encourages municipalities to provide schools that accommodate all 9 classes of basic education. These unified comprehensive schools comprised 24\% of all comprehensive schools in Finland in 2013 (Tilastokeskus, 2014). Other schools either catered for classes 1-6 (former primary schools) or for classes 7-9 of comprehensive schooling (former lower-secondary schools), which are sometimes, but not always, in the same building as the upper-secondary school.
} 
curriculum that emphasises one or more particular subjects. The selection may be based on the results of aptitude tests in those subject areas (Basic Education Act 628/1998: 28§): both these of these aspects are commonly known as school choice in urban Finland (see Seppänen et al., 2015a; 2015b; Seppänen \& Kosunen, 2015). Policies on choice in Finland do not include private provision of basic education as is the case in the extreme types of market-led systems (see e.g., Bunar, 2010; Seppänen et al., 2015b). Policies of school choice providing possibilities for more individualised educational solutions within the public education system have influenced the structure and the idea of non-selective comprehensive schooling, particularly in urban areas, and introduced new forms of competition and selection.

Bernelius (2013) has for example shown how school choice affects learning outcomes on an across-school level in Helsinki, so that the schools with the highest absolute scores in city-wide testing at the end of $9^{\text {th }}$ grade are performing better than expected in relation to the socio-demographic characteristics of their neighbourhood. On the other hand, the performance of schools at the lowest end is worse than would otherwise be expected. In a study artificially reallocating students to their nearest neighbourhood schools, the difference in performance between the highest scoring and lowest scoring schools was found to grow significantly after school choices: in a "no choice" scenario, the difference was almost seven percent points smaller than the actual difference after school choices. The outcomes were measured by percentage scores in sample-based standardised tests. The student flows increased the standard deviation in the school outcomes by more than 50 percent across all schools, from 4.2 to 6.4 , while the range grew from 42 to 60 score points to a range from 39 to 63 . (Bernelius, 2013.) Furthermore, the school performance of pupils has been shown to differ most strikingly between the general and selective classes within rather than across schools (Berisha \& Seppänen, 2016).

This study was conducted in one of the wealthiest municipalities in the western metropolitan area of Helsinki, in the city of Espoo with its 270,000 inhabitants (in 2015). The average per-capita annual income in Espoo in 2009 was EUR 34,123, which was higher than in Helsinki (EUR 28,708). Espoo has a few centres with a concentration of services and industry, which include some of the leading hubs of IT development in Finland. Large parts of the city are predominantly relatively wealthy neighbourhoods comprising single-family homes, including some of the most prestigious suburban concentrations in the metropolitan region. On the other hand, there are some relative concentrations of poverty and ethnic minorities, especially in the older high-rise areas. The effects of parental choice is an even more interesting question, given that the level of socio-economic and ethnic segregation within the urban space is relatively low in all Finnish cities by international comparison. ${ }^{3}$ It

\footnotetext{
${ }^{3}$ Finnish cities traditionally have very low levels of segregation due to strong governmental welfare policies and active municipal policies promoting social mix. This is reflected in the relatively small between-school variation in the pupil base. However, recent studies indicate a trend of growing
} 
could thus be argued that the pressure to opt out of certain schools is lower than in more segregated contexts, and Finnish educational policies have long been based on assumptions of equality and zero sorting effects on school choice.

This study concentrates on inter- and intra-district public-school choice. Seven districts, which in the Finnish context are called pupil-catchment areas, divide the city into geographical and governmental areas within which the municipality appoints a local school for every child. There are three to five schools in each catchment area. Families may express a preference from among these schools, or actively apply to any of the schools in the city offering classes with a special emphasis. (Espoo city, 2010.) The schools select pupils for these classes mainly by means of aptitude tests assessing skills in the emphasised subject area, such as music, sports or science, as part of the admission process. In practice the selected pupils constitute a permanent study group (referred to as the music class, the maths class or the sports class, for example), and thus we call them selective classes. The school-choice space for families in the case city Espoo consists mainly of public schools (25 out of 27 lower-secondary schools, the two remaining ones being state-subsidised independent schools). Selective classes are taught in at least one school in each of the seven catchment areas. For reasons connected to research ethics and to protect the anonymity of the schools and catchment areas, we do not give further details here, such as the total numbers of pupils in each catchment area or school.

\section{The study}

This study benefits from methodological triangulation, which is based on a combination of quantitative methods for collecting data on pupil statistics and socioeconomic distribution in a case city. We analyse pupil statistics and the enrolment of the whole age cohort $(\mathrm{N}=2,400)$ of $12-13$-year-olds attending lower-secondary schools in 2011 in Espoo. The empirical focus of this study is, first, on the influence of school choice on the social composition of schools, which also plays a role in their reputation, as has been widely studied (e.g., Kosunen, 2014), and second, on the connection between neighbourhood segregation and school segregation.

The social composition of schools derives from pupil enrolment, which could also be described as pupil flows from homes to schools within and across catchment areas. This process includes parental choice in line with municipal policies and the actual choices made by families. Earlier studies conducted in Finnish cities use terms such as popular, balanced and rejected schools based on statistics charting their in-between pupil flows (Bernelius, 2013; Seppänen, 2003). Thus far this has not been shown quantitatively as resulting in real pupil flows away from these schools towards others on the catchment-area level, nor as differentiation in their social composition, despite

segregation, especially in the metropolitan areas of the larger urban centres (see e.g., Bernelius, 2013: 22-48). 
what might be hypothesised. Drawing on previous analyses in urban Finnish schools (e.g., Berisha \& Seppänen, 2016; Kosunen \& Seppänen, 2015b; Seppänen et al., 2012b), we posit that the actual differences in the Finnish context might appear not on the across-school but rather on the within-school level. Within-school segregation as a finding would contribute relevant knowledge concerning the equality of education and opportunity in current comprehensive education in Finland. Investigating how pupil enrolment shapes schools in practice on the classroom level, in terms of the socio-economic composition of study groups, is thus interesting and a focus of our study.

We address two main research questions in this study. How and based on what strategies do pupils enrol in schools in the city of Espoo, in other words how do the pupil flows move in the city across schools within (intra-district) and across (interdistrict) catchment areas (4.1 and 4.2)? What are the interconnections between pupil enrolment from residential areas and the social composition of schools in the urban space, in other words from which residential areas are the distinctive choices made, and how does that relate to patterns of school segregation (4.3)?

We examined the socio-economic composition of the schools in relation to their close neighbourhood and the actual admission, in other words we investigated the connection between neighbourhood segregation and school segregation. First we defined the expected social composition of each school through the sociodemographic characteristics of its catchment area. Second, we determined the real social composition of each school based on the number of pupils enrolling in practice according to age-cohort statistics. ${ }^{4}$ We used databases created by Statistics Finland and the municipal authorities (Statistics Finland Grid Database, municipal building register $^{5}$ ) to approximate the socio-economic school aggregates for each school. Next we composed the expected school aggregates (Figure 1) for each school based on the residential address of the pupils - in other words we created an artificial close-tohome scenario for pupil intake (see Allen, 2007). For this we used a geographical model in which all pupils were reallocated to their nearest school within the borders of the administratively defined catchment area. In modelling the nearest school for each residential address we used the GIS (MapInfo) program to create a Voronoi diagram for the schools: this method has been used in similar studies (e.g., Östh, Andersson, and Malmberg (2013) in Sweden; see also Bernelius \& Vaattovaara, 2016). The limitation of this study is that we analyse the current residential situation in relation to the actual school admission, which includes the possibility of school choice: if there was no school choice, the 'choosing by mortgage' as a strategy could

\footnotetext{
${ }^{4}$ Place of residence is defined as the home address of the children. The school aggregates of social composition are based only on those statistical grids $(250 \mathrm{~m}$ x 250m, Statistics Finland Grid Database), in which the dwellings of the pupils investigated in this study (based on a building register) were located.

${ }^{5}$ For more information about the register go to: http://www.tilastokeskus.fi/tup/ruututietokanta/index_en.html
} 
be applied more and thereby the level of residential segregation could be something different. However, in this form the study provides relevant insights to the relation between neighbourhood segregation and inequalities in school admission in the current residential situation.

Drawing on the numbers of residents with higher education (a Master's degree or higher) and the mean income in each statistical grid with pupils of this age cohort, we approximated an expected socio-economic profile for each school. Then we compared this school aggregate to the actual pupil intake, where the background characteristics of the pupils' residential areas were attributed to the schools into which the pupils were admitted in practice. Third, we investigated each school on the basis of (1) pupils admitted to selective classes and (2) pupils enrolling with an additional language choice (e.g., German, French, Swedish or Russian) and compared these with pupils making a "regular" lower-secondary-school choice (general class and English as the only foreign language studied extensively) in each school.

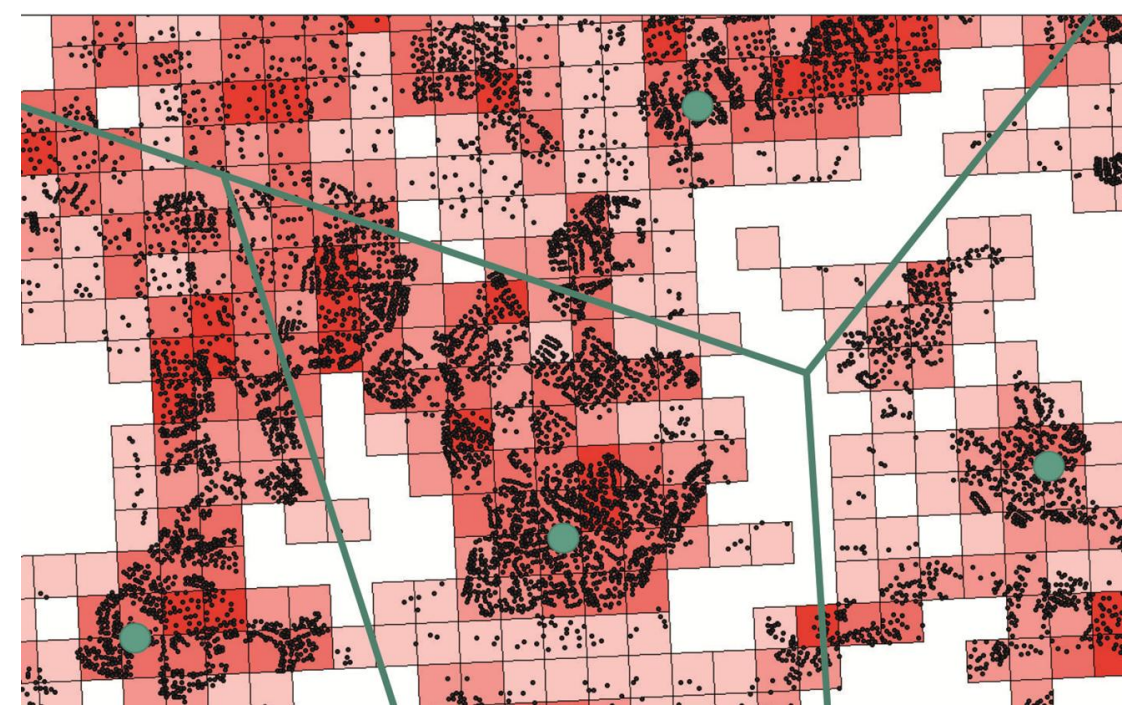

Figure 1. An illustration of the GIS method used for expected school aggregates: the grid database (red), homes (black), school buildings and artificial catchment areas for each school (green)

Next we discuss the results, and in the final section we draw together the findings on pupil flows and the social composition of schools, and elaborate on the implications given the assumed uniform nature of the Finnish comprehensive school.

\section{Results}

We present the results of the conducted analyses on two levels: first, by analysing pupil flows to schools within (4.1) and across (4.2) catchment areas; and second (4.3), by examining the actual social composition of each school and comparing that with the expected neighbourhood composition. In our conclusions we aim to elaborate 
empirically on the school-segregation phenomenon by combining the analyses of school choice, urban segregation and pupil composition.

We analysed pupil enrolment into lower-secondary schools in each of the seven catchment areas of the city of Espoo. On the city level, the average proportion of all pupils attending selective classes was 24.3 per cent $(n=584)$ of the age cohort $(\mathrm{n}=2400)$ participating in public schooling. Of the pupils living in Espoo and attending selective classes within their own catchment area 60 per cent were in selective classes in general $(n=353)$, and 40 per cent $(n=231)$ attended selective classes in other than their own catchment area (i.e. enrolled across areas). We therefore investigated the two different flows: pupil mobility within and across catchment areas. ${ }^{6}$

\subsection{Escape from disfavoured classes within catchment areas}

Analyses of the pupil flows within each of the seven catchment areas (intra-district choice in areas A to $G$ ) revealed some variation in mobility.

Area A had the smallest level of enrolment in selective classes within the catchment area, as only 16.3 per cent $(n=7)$ of the pupils also lived in the area. The provision of selective classes was very limited. The rest of the pupils studying in selective classes in the area enrolled from other areas of the city (and even neighbouring cities). Pupils exercising a within-area choice gained access to highly competitive groups in that the classes drew their pupils from all the other catchment areas across the city. This shows that these selective classes do not really serve the local catchment area because they could only accept a few of the pupils living in it. ${ }^{7}$ Interestingly, this catchment area does not offer many selective classes and therefore local pupils wishing to enrol in one would need to do so in other areas. Almost 16 per cent of them did so. Even if the underlying policy of providing selective classes in all catchment areas is implemented in terms of equal access to specialised education, it was not happening in catchment area A, where the selective classes did not serve the local community.

Of all the pupils in catchment area B, 17.5 per cent $(n=96)$ attended selective classes in the area, which was the highest proportion among the seven areas. In addition, 10.2 per cent of the pupils in area $B(n=56)$ chose to enrol for a selective class elsewhere. The selective classes in the area mainly served the local children: 93.2 per cent of the enrolled pupils also lived in the area. The long distances between schools and the urban limitations could also have affected the choices made in area B, as there may have been reluctance among pupils (or their parents) to cross a major road or other

\footnotetext{
${ }^{6}$ The city's two private (state-subsidised independent) schools accommodated 38 pupils, which is less than $1.6 \%$ of the whole age cohort $(n=2,438)$. Their enrolment is analysed separately. These pupils are excluded from the sampling regarding the numbers of pupils enrolling in public schools in each catchment area in the following sections, unless otherwise mentioned. The number of pupils in the cohort enrolled in public education is 2,400 .

${ }^{7}$ However, the number of applicants from the local catchment area was unknown so we could not determine the real acceptance rate in relation to the number of local applicants.
} 
large streets on their way to school. An interesting phenomenon in area B was that, unlike in area A, the selective classes seemed primarily to serve the local inhabitants. The provision of selective classes in area B was extensive. It seems from these extreme cases (areas A and B) that the provision of real options in the catchment area influences the number of choices in terms of within-area enrolment in selective classes. The interesting question of who is doing the choosing remains.

Choosing a selective class was a way of avoiding the general class in the local school, as described in area B. Another strategy emerged in catchment area C: a double strategy that, in addition to the choice of a selective class included an early choice of a foreign language in addition to English (e.g., French, German, Russian, Spanish or Swedish). In our earlier qualitative studies we refer to the teaching of a rare, additional language (Kosunen, 2014; Seppänen \& Kosunen, 2015) as a "soft" strategy in the context of school choice. In catchment area C, 17.9 per cent of all pupils attended selective classes within the area, nearly half of them adopting the double strategy of an emphasised subject and an additional language. With one exception, all of the pupils with a double strategy lived geographically closest to a school that appeared among the disfavoured ones, which reflected pupil mobility in area B. However, unlike in area B, enrolment into a school within the catchment area other than the local one in area $\mathrm{C}$ required multiple strategies. Adopting a double strategy requires the willingness and the capacity in the family to choose twice (the language in primary school and the selective class in primary or lower-secondary school): this could be considered an elaborated strategy. In magnitude it also seems to be consistent. In addition, the choices within the catchment area were mainly aimed at certain schools, which were therefore fairly oversubscribed. Without the double strategy, accessing the schools from a longer distance might have been difficult.

The qualitative analyses of the interviews with parents in the same area (Kosunen, 2014) indicated that families applied for children to study rare languages to avoid the local school. However, the quantitative analysis of pupil statistics implied that the choice of an additional foreign language as a sole strategy in certain areas did not guarantee access to a particular school. The use of a double strategy, i.e. a selective class and an additional language, requires different forms of capital from the family: economic to cover the costs of the school journey, social to acquire knowledge concerning the options, and cultural, given that the child needs to pass aptitude tests and be willing to study the chosen language, and that the parents need to be willing and able to conduct the choice as a bureaucratic process. These requirements might work as a hidden but significant mechanism, and go far in explaining how educational trajectories become diversified in contemporary basic education in urban Finland.

\subsection{Mobility towards prestigious classes across catchment areas}

Analyses of parental school choices across catchment areas (inter-district choice) revealed certain between-area (A-G) differences in logic (Figure 2). Some of the 
schools in two catchment areas (A and C) enrolled significantly more pupils from catchment areas other than their own in their selective classes. Simultaneously, the general (non-selective) classes in some of the schools seemed to "push" some pupils into choosing selective classes, as mentioned earlier, often within but also across catchment areas. ${ }^{8}$ Across the catchment areas the selective classes with a desirable reputation seem to "pull" a lot of pupils from other areas, as previously noted in connection with the logic of pupil enrolment in area A. Hence, some of the choices to cross also took place in catchment areas with a disfavoured school, but only in certain schools with selective classes. Thus having a specific school with disfavoured classes neither ruins the reputation of the whole catchment area nor diminishes the numbers of children enrolled in it. This is an interesting notion, implying not only the emergence of a push factor, but also that some classes pull pupils across areas.

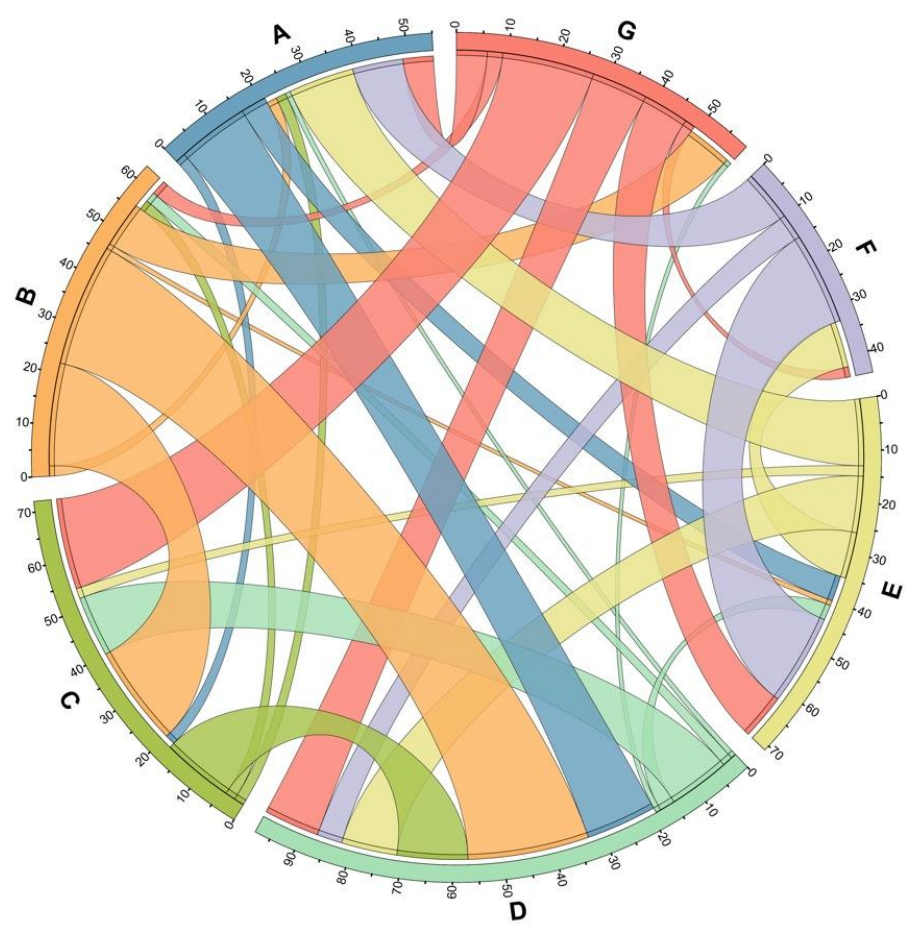

Figure 2. Pupil flows across catchment areas in the city of Espoo.

Figure 2 shows the emerging pupil flows across all catchment areas (i.e. the number of pupils enrolling in other than their own area). The lines between the different nodes represent the numbers of pupils transferring from one catchment area to another (not to particular schools), as these movements require intentional cross-catchment area

\footnotetext{
${ }^{8}$ Choosing a rare language as the sole strategy functioned only intra-district, within the catchment area, due to local educational governance.

${ }^{9}$ Nodes A-G represent the seven catchment areas. The areas are designated a colour. The colours of the lines indicate the origin and strength of the pupil flows (n). For example, from area A (blue) there is an exchange of about 60 pupils: about 20 leave the area (blue line leaving area A) the majority of them enrolling in area D (light green). On the other hand area A receives a significant number of pupils from areas $\mathrm{E}$ (yellow) and F (lilac). The same logic of receiving and sending out pupils applies to all the areas in Figure 2. Figure was created using Circos (Krzywinski et al. 2009).
} 
choices of selective classes. The catchment areas are organised in a geographically random order, which does not reflect their geographical closeness. As is evident, pupil flows emerge from all areas. A large proportion of the enrolment takes place in certain selective classes in areas A, C, D and E. Only minor pupil flows are targeted in the schools of areas $\mathrm{F}$ and $\mathrm{G}$.

Interestingly, only one of the selective classes in the whole city (in catchment area A) enrolled pupils from all the other areas. In general, pupils enrolled in schools near the few urban centres. Not many chose selective classes further from such a centre than their home was. It seems that those living in more rural parts of the city where the journey to the local school might be longer than 10 kilometres, fairly frequently chose other than the "local" school. It could be speculated that as the length of the journey was long anyway, a few more kilometres did not matter as much as it would to those living a shorter distance from school. Among the pupils crossing a catchment-area boundary for reasons of school choice, the highest percentage of those living in a single postal-code area lived in the rural part of the city.

In the case of the two private schools, which were pedagogically or religiously oriented and fully state-subsidised independent schools, no such consistent logic of enrolment within or across catchment areas (which do not apply to them) was evident. The pupils were all individually enrolled in the school via active admission in the whole metropolitan area. Many of them lived relatively near to the school, in other words it was easily accessible to them via public transport. Some enrolled from surrounding municipalities, given that the provision of pedagogically and religiously oriented schools in the metropolitan area is scarce. However, no straightforward consistency in private-school enrolment was apparent.

It seems that many of the selective classes served their own local catchment area, and pupils were even more likely to apply to them if the catchment area had a school with disfavoured non-selective classes. If the selective classes were limited in number, however, many pupils enrolled in other catchment areas, as might be expected. Those leaving their catchment area tended to enrol in one that was among the nearest. For example, in the case of area A the majority of pupils enrolled only in the geographically closest alternative, whereas those from areas B and C were spread among almost all the other areas. It could be speculated that the urban environment and the organisation of public transport has an impact on mobility in catchment areas without disfavoured schools, given that pupil enrolment in selective classes was fairly balanced among those enrolling from within the catchment area and from other areas across the border: all the selective classes in areas without disfavoured schools took about half of their pupils from the local area and the other half from a few other areas. This was not the case in catchment areas with disfavoured non-selective classes in any of its schools. 
Some selective classes drew many pupils from other areas across the city. Indeed, pupils from the local catchment area were often a minority in relation to pupils from other areas in the most prestigious selective classes, and if the local provision only included prestigious classes, the potential choices for local children were very limited in practice. The variance in competition for study positions thus relates to the less than total equality of opportunity across catchment areas, in which the logics of action varied. In practice, the possibilities of choosing schools across the catchment areas of the city differ. The existence of a school with disfavoured classes, or one with highly competitive selective classes, influences the local logic of action with regard to school choice. Some general classes seem to "push" pupils and some selective classes seem to "pull" them.

\subsection{The social composition of schools: mechanisms of segregation}

In this section we present the findings concerning social segregation between and within schools. There were noticeable between-school differences in the pupils' residential SES background. The schools with the lowest SES profile had an intake of pupils in whose residential blocks, on average, only a little over 11 per cent of adults have a higher tertiary degree. The respective average figure was over three times as high in schools with the highest social profile, with up to an average of 36 per cent of highly educated adults (MA or higher) in their pupils' residential blocks. This shows that the schools function in a differentiated environment.

However, according to the analysis of the interconnection between school choice and the social composition of schools, between-school segregation appears to be affected only moderately: school choices do not advance the school-segregation process in a statistically significant way, compared to the scenario in which the pupils are artificially reallocated to their geographically closest schools. There were only minor differences in the school averages with regard to socio-economic profiling when expected and actual admissions were compared, accounting for only a few percentage-point changes in the SES composition of each school. In short, although there were strong pupil flows, they did not appear to have a big effect on school composition measured in terms of the pupils' residential SES status and on the general school level: the existing differences did not increase, but neither do they decrease.

The relative stability of between-school segregation does not mean that choice does not act as a driver of increasing segregation in socio-economic terms. The connection between pupil selection and segregation was even more evident in the analysis of pupils opting for choice. Closer scrutiny of the ways in which choices of selective classes and of additional languages were conducted revealed some consistency: pupils from grid database squares or blocks with a higher socio-economic profile were significantly over-represented in both groups. In other words, pupils opting for a selective class or another language came from residential blocks with a statistically 
significantly higher SES status compared with the blocks of other pupils (Table 1). The effect was strongest among those who had adopted the double strategy, in other words who had opted for both the selective group and an additional language. Pupils in the non-selective groups lived, on average, in residential blocks in which one third of the adults had a tertiary education, the corresponding average figure among those opting for both selective groups being 37 per cent. The difference in yearly household income between pupils in selective and non-selective streams in terms of their residential blocks was almost 10,000 euros, representing more than 14 per cent. Given that the formation of study groups in schools tends to be based on the choices made, this creates significant within-school segregation.

Table 1. The estimated SES-profiles of pupils in comprehensive schools: pupils without additional choices (general), pupils with selective choice (only), pupils with additional language choices (only) and pupils with the double strategy (selective choice and an additional language). All groups with selective choices differ statistically significantly $(p<0.001)$ from the non-selective group (flagged with *).

\begin{tabular}{|c|c|c|c|}
\hline & \multicolumn{3}{|c|}{$\begin{array}{l}\text { Socio-economic characteristics of the students' } \\
\text { residential blocks }\end{array}$} \\
\hline & $\begin{array}{ll}\text { Adults with } \\
\text { tertiary } \\
\text { education }\end{array}$ & $\begin{array}{l}\text { Adults with only } \\
\text { basic education }\end{array}$ & $\begin{array}{l}\text { Yearly income } \\
\text { (€/ household) }\end{array}$ \\
\hline $\begin{array}{l}\text { Pupils without additional } \\
\text { choices (general) }\end{array}$ & $33.1 \%$ & $22.8 \%$ & 69694 \\
\hline Pupils with selective choice & $36.7 \% *$ & $20.2 \% *$ & 77927* \\
\hline $\begin{array}{l}\text { Pupils with additional } \\
\text { language choices }\end{array}$ & $36.9 \% *$ & $19.8 \% *$ & $77814^{*}$ \\
\hline $\begin{array}{l}\text { Pupils with double strategy } \\
\text { (selection and language) }\end{array}$ & $37.3 \% *$ & $19.7 \% *$ & $79284^{*}$ \\
\hline
\end{tabular}

Despite the fact that the selective class and language choice are intentionally treated as separate factors here, many of the pupils who chose an additional language were also in a selective class (as noted in section 4.1 with reference to double strategies in school choice). The emerging differences across schools thus seem to be only the tip of the iceberg: real socio-economic differences across general pupils and those selected in some sense consistently emerged within schools in the whole age cohort. The most interesting finding is that these results held even when approximating the social composition of the groups only with the characteristics of the pupils' residential block. In other words, the connection across residential areas and social selection

\footnotetext{
${ }^{10}$ This group contains all pupils in general classes with no additional choices and pupils in special education.
} 
related to school choice is also evident in the case of urban Finland, which has not previously been shown empirically.

This does not mean that only pupils from higher socio-economic backgrounds are able to apply for selective classes, or choose additional languages from early on, however: these two processes just seem to work as mechanisms and socially distinctive practices, both of which have implications for the everyday practices of schools, their classes, families and children.

The functioning of the educational system in Finland no longer rests on the idea that selective classes and additional languages, as part of the publicly funded tuition-free education of all children, primarily serve the interests of "talented and motivated" pupils, as was assumed in the political discourse (Seppänen, 2003) from all social classes. The basis on which "talented" is defined also needs to be re-evaluated (Kosunen \& Seppänen, 2015a). A connection with educational choice emerges in relation to the children's social background. Given that urban segregation is fairly low by international standards in the case city of Espoo, these results give a notable indication of urban segregation and socio-economic stratification. There is a noticeable effect of choice-led policies, which strengthen segregation within schools even in the egalitarian Finnish context.

\section{Conclusion}

The research task was to explore pupil flows across schools in the city within (intradistrict school choice) and across (inter-district school choice) catchment areas, the strategies used and the residential areas in which the choices are made. The larger question related to all this was to investigate how these school choices emanating from different residential areas relate to patterns of school segregation.

Two distinctive strategies of school choice within the public comprehensive education system in the city of Espoo were identified: opting for emphasised teaching (selective classes) and opting for rare languages. Opting for emphasised teaching, and thus a selective class, enabled both intra-district and inter-district (see Berends, 2014) school choices. Opting for a rare foreign language only facilitated intra-district choices, but basically operated as a way of avoiding a certain school in the catchment area that did not offer that particular language in its study programme. It has been suggested in previous studies (Kosunen, 2014; Seppänen \& Kosunen, 2015) that language choices work as "soft" school-choice strategies, but it is not known to what extent this practice is applied across city neighbourhoods. It was found in this study, covering all $7^{\text {th }}$-graders of the city, that the choice of a rare language was an active strategy applied primarily by families from better-off residential blocks. This relates to Reay's (2004) observation about how well-off families high on economic and cultural capital often aim and manage to find their ways of exiting the 'sinking' schools within a public education system. The way of exiting the local school via choices of selective 
schooling is an obvious strategy applied by these families shown also in our study, but also the choice of rare language seems to function as a exit strategy in urban Finland.

The provision and accessibility of selective classes seemed to affect the number of mobile pupils making choices. The choices within catchment areas were influenced by the presence of a school that seemed to push away pupils from higher socioeconomic residential blocks (push-factor), which in previous studies in other Finnish cities (Bernelius, 2013; Seppänen, 2006) has been referred to as the rejected-school phenomenon. This finding confirms insights from previous studies suggesting that many parents avoid disreputable schools (e.g., Kosunen, 2016). However, it appears from this study that these choices tend to emanate from better-off residential blocks. The intra-district and inter-district choices in such catchment areas were numerous, and functioned in relation to attractive selective classes (pull factor) in some schools. Some of the selective classes managed to pull pupils from all around the city, which resulted in very long school journeys. Thus the practices of choosing within a catchment area or choosing across catchment areas were somewhat different, yet partially interconnected. One could speculate that these two sets of choices, motivated by pull and push factors, are somehow different in kind, which would require further qualitative inquiry.

When the expected and actual socio-economic pupil composition in schools were compared on the aggregate level, the parental choices did not result in de-segregation across schools, as also noted elsewhere with regard to patterns of school segregation (e.g., Holme, 2002). The socio-economic differences across schools were as wide as they would have been if all pupils were allocated to the nearest lower-secondary school. School choices rather contributed to within-school segregation through the choice of rare languages and selective classes (singly and in combination) when the school grouped its pupils accordingly. Our findings from the city of Espoo in Finland show that, despite the egalitarian reputation of comprehensive education, schoolchoice policy allowing selection and grouping practices enable urban families from well-off residential areas to maintain their children in socially advantaged school settings. These findings are new and somehow surprising in the Finnish context, even though similar findings have been reported in other contexts (see e.g., Thrupp, 2007). As a consequence, drawing on Reay's (2004) view of school choice as relational and interdependent, the study groups from which these pupils opt out are at a relative disadvantage.

\section{Discussion}

As shown in the analyses, the impact of language choice as a diversifier was only slightly smaller than that of the selective classes. The socially differentiating effect of choosing an additional language and using it as an exit-practice within the public education (see Reay, 2004) is a new discovery in the Finnish context. Moreover, the choice of a rare language could be predicted on the basis of the socio-economic status 
of the residential block of the child. This has two theoretically interesting implications. First, our analysis demonstrates that differentiation between schools is not necessarily one of the main mechanisms of school segregation in Finland, but that differentiation between classes within schools may be, and this has a strong connection to the socio-economic background of the pupils. This finding is in line with those reported in qualitative studies based on interviews and survey-based quantitative studies (see Seppänen et al., 2015a). This study presents the full extent into which the differentiation between schools may be connected to within- and across-school segregation, and participate in the construction of hidden but obvious streaming within public education system.

Another implication is that, contrary to what is generally assumed about the egalitarian nature of Finnish society, the educational system and urban neighbourhoods, the relationship between educational stratification and urban segregation is strong enough to allow the socio-economic status of the pupils' residential block to be used as a predictor of their educational choices. This finding contradicts long-held assumptions. Specifically, it contradicts the belief that the Finnish educational system and urban areas operate in an egalitarian manner along the following lines. The egalitarian effect of the system was assumed only in as far as the capacity and willingness of parents to choose constituted a resource similarly available to all families in all residential locations, regardless of socio-economic status. The fact that these choices are linked not only to the pupils' background but also to the status of their residential location is a stark contradiction of this assumption.

The strong link between the educational choices of the pupils and the residential status of their neighbourhood may carry implications outside of the educational institutions. It has been shown that the processes of socio-spatial and school segregation are interlinked through the residential choices of families (Bernelius \& Vaattovaara, 2016; Dhalmann et al., 2014) and the spatial selection of pupils to their neighbourhood schools. Up until now these processes have been moderate in Finnish cities. Thus, not only do the findings of this study question the egalitarian nature of Finnish schools and school choices, they also demonstrate surprisingly far-reaching micro-level segregation in the residential patterns of families. What this means in an everyday context is that the developmental context in the neighbourhood of the pupils is differentiated in a similar manner as the classrooms in the schools they attend. This finding contradicts the national ideal of mixed neighbourhoods in which children interact with people from different social backgrounds.

Providing school-choice options has led to (socially biased) pupil flows across the city from residential areas with higher socio-economic profiles to desirable classes in different schools. It can therefore be speculated that the societal and urban environment in which such choices are currently being made has changed from the one in which the school-choice system was constructed a few decades ago. This 
becomes a matter of hidden distinctions produced and reproduced via school choice leading to social selection in urban Finland too, despite the public and presumably egalitarian intentions embedded in the comprehensive educational system. These findings offer insights into the international debate on school choice and equality: they demonstrate that even in the Finnish urban landscape with relatively low levels of urban segregation in international comparisons, segregation processes operate through spatial micro-level distinctions and social-avoidance strategies used by the higher social classes, as has been reported happening in various contexts (see e.g. Ball et al., 1995; Ball, 2003; Reay, 2004; Thrupp, 2007; van Zanten, 2009). In other words, the choices are used as an exclusionary tactics, they reproduce differentiation between schools and extend the differences especially between classes within schools. In conclusion, the assumption that school choice provides more equal educational opportunities and promotes the old Nordic ideal of one school for all, should be questioned (see Lundahl, 2016) also in the context of urban Finland.

\section{References}

Allen, R. (2007). Allocating pupils to their nearest secondary school: The consequences for social and ability stratification. Urban Studies, 44(4), 751770 .

Andersson, E. K., \& Malmberg, B. (2015). Contextual effects on educational attainment in individualised, scalable neighbourhoods: Differences across gender and social class. Urban Studies 52(12), 2117-2133.

Ball, S. J., Bowe, R. \& Gewirtz, S. (1995). Circuits of Schooling: A Sociological Exploration of Parental Choice of School in Social-Class Contexts. The Sociological Review, 43, 52-78.

Ball, S. J. \& Vincent, C. (1998). 'I Heard It on the Grapevine'. 'Hot' Knowledge and School Choice. British Journal of Sociology of Education, 19(3), 377-400.

Ball, S. J. (2003). Class Strategies and the Education Market: The Middle Classes and Social Advantage. London: Routledge Falmer.

Berends, M. (2014). The Evolving Landscape of School Choice in the United States. In H. R. Milner IV \& K. Lomotey (eds.) Handbook of Urban Education. New York \& London: Routledge, 451-473.

Berisha, A-K. \& Seppänen, P. (2016). Pupil selection segments urban comprehensive schooling in Finland. Composition of school classes in pupils' school performance, gender, and ethnicity. Scandinavian Journal of Educational Research. DOI: 10.1080/00313831.2015.1120235.

Bernelius, V. (2013). Eriytyvät kaupunkikoulut: Helsingin peruskoulujen oppilaspohjan erot, perheiden kouluvalinnat ja oppimistuloksiin liittyvät aluevaikutukset osana kaupungin eriytymiskehitystä. Tutkimuksia 1/2013. Helsingin kaupungin tietokeskus, Helsinki.

Bernelius, V. \& Vaattovaara, M. (2016). Choice and segregation in the 'most egalitarian' schools: Cumulative decline in urban schools and neighbourhoods of Helsinki, Finland. Urban Studies. Published online before print February 16, 2016, DOI:10.1177/0042098015621441. 
Bourdieu, P. (1984). Distinction: A social critique of the judgement of taste. Cambridge: Harvard University Press.

Bråmå, Å. (2006). "White flight?” The production and reproduction of immigrant concentration areas in Swedish cities, 1990-2000. Urban Studies, 43(7), 1127-1146.

Butler, T. \& Hamnett, C. (2007). The geography of education: Introduction. Urban studies, 44(7), 1161-1174.

Butler, T. \& Robson, G. (2003). Londong calling. The Middle Classes and the ReMaking of Inner London. Oxford: Berg.

Bunar, N. (2010). Choosing for quality or inequality: current perspectives on the implementation of school choice policy in Sweden. Journal of Education Policy, 25(1), 1-18.

Collins, D. \& Coleman, T. (2008). Social Geographies of Education: Looking within, and Beyond, School Boundaries. Geography Compass, 2/1, 281-299.

Crozier, G., Reay, D., James, D., Jamieson, F., Beedell, P., Hollingworth, S. \& Williams, K. (2008). White Middle-class Parents, Identities, Educational Choice and the Urban Comprehensive School: Dilemmas, Ambivalence and Moral Ambiguity. British Journal of Sociology of Education, 29(3), 261-272.

Curran Neild, R. (2005). Parent Management of School Choice in a Large Urban District. Urban Education, 40(3), 270-297.

Dhalmann, H., Vaattovaara, M. \& Vilkama, K. (2014). Hyvää kasvuympäristöä etsimässä - Asuinalueen ja koulun merkitys lapsiperheiden muuttopäätöksille pääkaupunkiseudulla. Yhdyskuntasuunnittelu, 51(4), 11-29.

Dovemark, M. \& Holm, A-S. (2015). Pedagogic identities for sale! Segregation and homogenization in Swedish upper secondary school. British Journal of Sociology of Education, 1-12. DOI:10.1080/01425692.2015.1093405.

Espoo city (2010). Yläkoululaisen opas. Espoo: City of Espoo.

Gewirtz, S., Ball, S. J. \& Bowe, R. (1995). Markets, Choice and Equity in Education. Buckingham: Open University Press.

Hautamäki, J., Kupiainen, S., Marjanen, J., Vainikainen, M.-P. \& Hotulainen, R. (2013). Oppimaan oppiminen peruskoulun päättövaiheessa.Tilanne vuonna 2012 ja muutos vuodesta 2001. Tutkimuksia 347. Helsingin yliopisto: Opettajankoulutuslaitos.

Holme, J. J. (2002). Bying Homes, Bying Schools: School Choice and the Social Construction of School Quality. Harvard Educational Review 72 (2), 177-205.

Hursh, D. (2015). Deceptive data: How the corporate reform movement uses standardized tests to achieve the neoliberal agenda. In A. Costigan \& L. Grey (eds.), Demythologizing educational reforms: Responses to the political and corporate takeover of education. New York: Routledge, 104-116.

Kortteinen, M. \& Vaattovaara, M. (2015). Segregaation aika [Time of Segregation]. Yhteiskuntapolitiikka, 80(6): 562-574.

Kosunen, S. (2014). Reputation and parental logics of action in local school choice space in Finland. Journal of Education Policy, 29(4), 443-466. 
Kosunen, S. \& Seppänen, P. (2015a). The transmission of capital and a feel for the game: Upper-class school choice in Finland. Acta Sociologica, 58(4), 329-342.

Kosunen, S. \& Seppänen, P. (2015b). "Helky laulu, kaiu maine": koulujen maineiden rakentuminen ja opetusryhmien mainehierarkiat kaupungeissa. In P. Seppänen, M. Kalalahti, R. Rinne and H. Simola (Eds.), Lohkoutuva peruskoulu Perheiden kouluvalinnat, yhteiskuntaluokat ja koulutuspolitiikka. Research in Education Sciences 68. Jyväskylä: Finnish Educational Research Association, 231-260.

Kosunen, S. \& Carrasco, A. (2016). Parental preferences in school choice: comparing reputational hierarchies of schools in Chile and Finland. Compare: A Journal of Comparative and International Education, 46(2), 172-193.

Kosunen, S. (2016). Families and the Social Space of School Choice in Urban Finland. Helsinki: Unigrafia

Krzywinski, M., Schein, J., Birol, I., Connors, J., Gascoyne, R., Horsman, D., . . . Marra, M. A. (2009). Circos: an information aesthetic for comparative genomics. Genome research, 19, 1639-1645.

Lauder, H., Hughes, D., Watson, S., Waslander, S., Thrupp, M., Strathdee, R., Simiyu, I., Dupuis, A., McGlinn, J. \& Hamlin, J. (1999). Trading in Futures: Why Markets in Education Don't Work. Buckingham: Open University Press.

Lundahl, L. (2016). Equality, inclusion and marketization of Nordic education: Introductory notes. Research in Comparative \& International Education, 3-12. Published online before print February 14, 2016, doi: $10.1177 / 1745499916631059$.

Lubienski, C. (2009). Do Quasi-Markets Foster Innovation in Education? A Comparative Perspective. OECD Education Working Paper No. 25. Paris: Organisation for Economic Cooperation and Development.

Malmberg, B., Andersson, E. K. \& Bergsten, Z. (2014). Composite Geographical Context and School Choice Attitudes in Sweden: A study based on individually defined, scalable neighborhoods. Annals of the Association of American Geographers, 104(4), 869-888.

Ministry of Education (2007). Koulutus ja tutkimus vuosina 2007-2013.

Kehittämissuunnitelma. Helsinki: Ministry of Education.

Ministry of Education and Culture (2012). Education and Research 2011-2016. A development plan. Reports of the Ministry of Education and Culture, Finland 2012:3.

Mitchell, D. E., Batie, M. \& Mitchell, R. E. (2010). The Contributions of School Desegregation to Housing Integration: Case Studies in Two Large Urban Areas. Urban Education, 45(2), 166-193.

Oberti, M. (2007). L'école dans la ville. Paris: Presses de Sciences Po.

OECD (2014). PISA 2012 Results in Focus. What 15-year-olds know and what they can do with what they know. PISA, OECD Publishing, Paris.

Power, S., Whitty, G., Edwards, T. \& Wigfall, V. (2003). Education and the Middleclass. Buckingham: Open University Press. 
Raveaud, M. \& van Zanten, A. (2007). Choosing the Local School: Middle Class Parents' Values and Social and Ethnic Mix in London and Paris. Journal of Education Policy, 22(1), 107-124.

Reay, D. \& Lucey, H. (2003). The limits of 'choice': Children and inner city schooling. Sociology, 37(1), 121-142.

Reay, D. (2004). Exclusivity, Exclusion, and Social Class in Urban Edcuation Markets in the United Kingdom. Urban Education, 39(5), 537-560.

Reay, D., Crozier, G. \& James, D. (2011). White Middle Class Identities and Urban Schooling. Palgrave Macmillan.

Rinne, R. (2000). The Globalisation of education: Finnish education on the doorstep of the new EU millennium. Educational Review, 52(2), 131-142.

Seppänen P. (2003). Patterns of 'public-school markets' in the Finnish comprehensive school from a comparative perspective. Journal of Education Policy, 18(5), 513-531.

Seppänen, P. (2006). Kouluvalintapolitiikka perusopetuksessa. Suomalaiskaupunkien koulumarkkinat kansainvälisessä valossa. Research in Education Sciences 26. Jyväskylä: Finnish Educational Research Association.

Seppänen, P., Rinne, R. \& Sairanen, V. (2012a). Suomalaisen yhtenäiskoulun eriytyvät koulutiet. Oppilasvalikointi perusopetuksessa, esimerkkinä Turun koulumarkkinat. Yhteiskuntapolitiikka, 77(1), 16-33.

Seppänen, P., Rinne, R. \& Riipinen, P. (2012b). Yläkouluvalinnat, koulujen suosio ja perheiden sosiaalinen asema - Lohkoutuuko perusopetus kaupungeissa? [School choice, school popularity and families' social status - segmentation of basic education in Finnish cities?] Kasvatus [The Finnish Journal of Education] 43(3), 226-243.

Seppänen, P. \& Kosunen, S. (2015). Eine finnische Einheitsschule? Subtile Schülerselektion in der Schulwahlpolitik in städtischen Gebieten Finnlands. In W. Helsper, H. H. Krüger (eds.), Auswahl der Bildungsklientel - Zur Herstellung von Selektivität in "exklusiven" Bildungsinstitutionen. Springer, 321-346.

Seppänen, P., Kalalahti, M., Rinne, R. \& Simola, H. (eds.) (2015a). Lohkoutuva peruskoulu - Perheiden kouluvalinnat, yhteiskuntaluokat ja koulutuspolitiikka. Research in Education Sciences 68. Jyväskylä: Finnish Educational Research Association.

Seppänen, P., Carrasco, A., Kalalahti, M., Rinne, R. \& Simola, H. (eds.) (2015b). Contrasting Dynamics in Education Politics of Extremes: school choice in Chile and Finland. Rotterdam: Sense Publishers.

Simola, H. (2015). The Finnish Education Mystery - Historical and sociological essays on schooling in Finland. London: Routledge.

Söderström, M. \& Uusitalo, R. (2005). School choice and segregation: evidence from an admission reform. Working paper 2005:7, Institute for Labour Market Policy Evaluation.

Taylor, C. (2002). Geography of the "new" education market. Aldershot: Ashgate.

Thrupp, M. (2007). School admissions and the segregation of school intakes in New Zealand cities. Urban Studies, 44(7), 1393-1404. 
Tilastokeskus (2014). Koulutuksen järjestäjät ja oppilaitokset 2013. Helsinki: Tilastokeskus.

van Houtte, M. \& Stevens, P. A. (2009). Study involvement of academic and vocational students: Does between-school tracking sharpen the difference? American Educational Research Journal, 46(4), 943-973.

van Houtte M., Demanet, J., \& Stevens, P. A. J. (2012). Self-esteem of academic and vocational students: Does within-school tracking sharpen the difference? Acta Sociologica, 55, 73-89.

van Zanten, A. (2009). Choisir son école: stratégies familiales et médiations locales. Paris: Presses Universitaires de France.

Vilkama, K. (2011). Yhteinen kaupunki, eriytyvät kaupunginosat? Kantaväestön ja maahanmuuttajataustaisten asukkaiden alueellinen eriytyminen ja muuttoliike pääkaupunkiseudulla [Shared City, Segregating Neighbourhoods? The Spatial Segregation and Mobility Patterns of Ethnic Groups in the Helsinki Area]. Helsinki: Helsingin kaupungin tietokeskuksen Tutkimuksia.

Välijärvi, J., Kupari, P., Ahonen, A. K., Arffman, I., Harju-Luukkainen, H.. Leino, K., Niemivirta, M., Nissinen, K., Salmela-Aro, K., Tarnanen, M., Tuominen-Soini, H., Vettenranta, J. \& Vuorinen, R. (2015). Millä eväillä osaaminen uuteen nousuun? PISA 2012-tutkimustuloksia. Opetus- ja kulttuuriministeriön julkaisuja 2015:6: Ministry of Education and Culture.

Östh, J., Andersson, E. \& Malmberg, B. (2013). School Choice and Increasing Performance Difference: A Counterfactual Approach. Urban Studies, 50(2): 407-425. 